\title{
International tax competition and justice: The case for global minimum tax rates
}

\author{
Andreas Cassee \\ University of Bern, Switzerland
}

Draft version accepted for publication in Politics, Philosophy \& Economics. The final version can be found at https://journals.sagepub.com/doi/10.1177/1470594X19848074

\begin{abstract}
International tax competition undermines states' capacity for redistributive taxation. It is thus problematic from the point of view of both cosmopolitan and internationalist theories of justice. This paper examines the proposal of a fiscal policy constraint that prohibits tax policies if they are strategically motivated and harmful to effective fiscal self-determination internationally. I argue that we should opt for a more robust, preference-independent mechanism to prevent harmful tax competition instead. States should, as a matter of justice, accept global minimum tax rates on mobile tax bases.
\end{abstract}

\section{Keywords}

Tax justice, tax competition, fiscal interdependence, minimum tax rates, fiscal selfdetermination, global justice 


\section{Introduction}

Justice in taxation was long considered a quintessentially domestic topic: Whatever the demands of justice in this area may be, they apply separately to individual states, considered in isolation from each other (cf. Rawls, 1971: 8; Murphy and Nagel, 2002: 41). Under conditions of economic globalization, this assumption has increasingly become untenable. Even if we assume that the power to tax falls squarely in the hands of individual states and disregard proposals for taxes to be raised at an international level, ${ }^{1}$ the fact that parts of the tax base are mobile across borders gives rise to questions of justice with an international reach (Brock, 2008; Ronzoni, 2009, 2014, 2016; Dietsch and Rixen, 2014a, 2014b; Dietsch 2015). Unhampered tax competition is problematic from the perspective of both cosmopolitan and internationalist theories of justice. According to cosmopolitanism, principles of distributive justice apply directly beyond state borders. On this view, international tax competition is worrying insofar as it leads to an unjust distribution of wealth (or some other currency of distributive justice) between individuals worldwide. According to internationalism, the scope of distributive justice between individuals is limited to the domestic context. However, there are international duties of justice to secure background conditions that enable states to realize just institutions domestically and entertain fair relations among themselves (Ronzoni, 2009). From an internationalist perspective, international tax competition is worrying to the extent that it undermines the effective fiscal self-determination ${ }^{2}$ of states or leads to a level of inequality between states that is incompatible with fair international relations (Dietsch and Rixen, 2014b; Ronzoni 2014, 2016).

This paper argues that both cosmopolitans and internationalists have reason to support global minimum tax rates to mitigate the harmful effects of international tax competition. It is organized as follows. Section 2 gives an overview of the mechanisms and effects of 
international tax competition. Section 3 discusses the normative grounds for seeing it as a problem of justice. Section 4 introduces two normative principles put forward by Peter Dietsch and Thomas Rixen (2014b) to address the problem of harmful tax competition. Section 5 criticizes their 'fiscal policy constraint' which asymmetrically restrains the option space of different countries depending on their non-strategic tax preferences. Section 6 introduces global minimum tax rates as a more robust, preference-independent mechanism to counteract downward pressure on the taxation of mobile tax bases. Section 7 discusses how the minimum tax rate should be set on various versions of cosmopolitanism and internationalism. Section 8 addresses the worry that global minimum tax rates might harm low-income countries that may have nothing but low tax rates to compete for capital on the global financial markets. Section 9 concludes.

\section{The mechanisms and effects of international tax competition}

Tax competition is a contested issue not only in normative theory, but also in the economic literature. This section gives a short overview of (a.) theoretical models of tax competition discussed in public economics, (b.) the strategies employed to lower the tax burden on capital in practice, and (c.) the effects of tax competition on the ability of states to raise taxes on mobile tax bases.

\section{a. Theoretical models of tax competition}

Tax competition occurs when jurisdictions strategically set their tax policies to attract a mobile tax base (Wilson and Wildasin, 2004). Not everybody agrees that such competition is problematic. Some think, quite to the contrary, that it enhances efficiency. One influential line of argument to this effect was first introduced by Charles Tiebout (1956) in the context of tax 
competition between subnational jurisdictions. Tiebout believes that tax competition is a solution to the problem that there is no market for public goods. His model predicts that the possibility to 'vote with one's feet' (Hirschman, 1970) and move to another jurisdiction where the bundle of public goods provision and tax burden is more to one's liking will ultimately lead to policies that more adequately reflect the preferences of the population.

However, it is important to note the limitations of the Tiebout model. First, it starts from the assumption that taxes are raised exclusively to supply public goods, and that the taxes paid by an individual roughly equal the costs of supplying her with those goods. Second, the model assumes that all taxpayers are perfectly mobile across jurisdictions at no considerable cost. Contrary to the first assumption, virtually all jurisdictions practice some kind of redistributive taxation, and according to most theories of justice, they should do so. Contrary to the second assumption, while capital is highly mobile across jurisdictions, this is much less true for persons, especially in the international case. States typically have legal restrictions on immigration in place, which are informed in part by the way immigration affects redistributive taxation (net taxpayers are generally more welcome than those creating net costs). While the moral justifiability of a right to exclude would-be immigrants is up for debate (Carens, 1987, 2013; Cassee, 2016), restrictions on immigration are a part of the present situation that should not be ignored. And even where no legal restrictions apply, migrating to another jurisdiction is typically a costly process, both in monetary terms and in terms of giving up personal relationships.

These shortcomings of the Tiebout model raise suspicion that, far from making governments more responsive to all taxpayers' preferences, tax competition will lead to a 'race to the bottom' with regard to the taxation of capital. This suspicion is substantiated by a model of capital tax competition originally developed by Zodrow and Mieszkowski (1986). The model 
assumes a fixed global capital stock that is perfectly mobile across a number of identical jurisdictions. Each jurisdiction individually fixes its rate of capital taxation and uses the tax revenue to purchase a single public good (like the Tiebout model, the Zodrow/Mieszkowski model does not take into account redistributive taxation). Capital after tax is used to produce a single private good. States optimize their tax rates so as to best satisfy the preferences of a representative consumer for private and public goods. Under these assumptions, tax setting by individual jurisdictions takes the form of a prisoner's dilemma. Each jurisdiction will rationally choose a tax rate that is lower than the optimal tax rate from an aggregate point of view.

The prediction of lower than optimal taxation is relatively robust, with some qualifications, for a number of changes to the model (for an overview, see Keen and Konrad, 2013; Clausing, 2016). A model that takes into account public spending in infrastructure for business and redistributive transfers indicates that spending in public infrastructure may be higher than optimal in a situation of tax competition, while redistributive transfers will be lower (Sørensen, 2004). In an asymmetric case with countries of different sizes, smaller countries will have stronger incentives to become tax havens, as the influx of foreign capital is comparatively more relevant for them than the reduction of tax revenue from capital already present in the country (Bucovetsky, 1991). The setting of capital tax rates, in this case, takes the form of an 'asymmetric prisoner's dilemma', where some jurisdictions benefit from the lack of coordination, though coordination could still be a Pareto improvement if side-payments were allowed (Rixen, 2008: ch. 3). Finally, a model that takes into account agglomeration effects shows that core states can hold on to mobile production factors even if their tax rates are somewhat higher than those in the periphery (Baldwin and Krugman, 2004). 


\section{b. Tax evasion and tax avoidance in practice}

The basic model of capital tax competition introduced in the last section and most of its extensions focus on a scenario where there is only one tax on capital, raised uniformly (but at different rates) by all jurisdictions, and there is only one way to lower the tax burden, namely by investing capital in a jurisdiction with a lower tax rate. ${ }^{3}$

In practice, capital taxation takes different forms. Corporate taxes typically make for around one third of the overall tax revenue on capital, with personal taxes on capital income and property accounting for the remaining two thirds (Zucman, 2014). Physically moving business operations or changing residence to a jurisdiction with lower tax rates is not the only, nor the most important, strategy employed to lower the tax burden in either case.

In the realm of personal taxation, there is a considerable amount of illegal tax evasion by wealthy individuals who hide taxable portfolio capital in tax havens that do not inform the country of origin about its existence. According to one estimate, at least eight percent of privately owned financial assets worldwide are stashed away in tax havens (Zucman, 2013). On the corporate side, a whole range of strategies of tax avoidance are employed (de Mooij and Ederveen, 2008). First, corporations reduce their tax burden by shifting profits to subsidiaries in jurisdictions with low or zero corporate taxation. For example, a multinational's subsidiary in a high-tax jurisdiction may reduce its profits on paper by paying exaggerated royalties for intellectual property to another subsidiary in a low-tax environment. Second, many jurisdictions grant preferential taxation to specific corporate bodies, thus giving companies an opportunity to lower their tax burden by adjusting their legal form. Third, a company's financial structure may also help to reduce its tax burden, as interest on debt is deductible from the corporate tax base as a cost. The combination of these strategies often gives rise to corporate structures of nearly comical complexity. ${ }^{4}$ 


\section{c. The effects of tax competition}

In the light of these strategies employed by corporations and wealthy individuals, states engage not only in 'real' tax competition for foreign direct investment and wealthy residents, but also in various forms of 'virtual' tax competition, where the relocation of tax base is not accompanied by a real change in where economic activity takes place or a person resides (Dietsch and Rixen, 2014b). Empirical evidence suggests that profit shifting, rather than competition for foreign direct investment, is the main driving force behind the global trend for lower statutory corporate tax rates (de Mooij and Ederveen, 2008). The OECD average statutory corporate tax rate at the central government level has declined from $41 \%$ in 1981 to $23 \%$ in 2014 (Clausing, 2016). ${ }^{5}$ In the same time period, there was also a widespread demise of inheritance taxation, as well as a reduction in top marginal rates of personal income taxation. The latter of these developments can be seen as a side-effect of lower corporate income taxes: If personal income were taxed at a much higher rate than corporate income, high-income individuals would have an incentive to avoid personal taxation by incorporating (Rixen, 2016).

As noted above, tax competition produces winners as well as losers, and for some winners (especially small OECD countries, but also some tax havens outside the OECD), the gain in tax base may outweigh the arithmetical effect of lower tax rates, so that their tax revenue increases overall (Genschel and Seelkopf, 2016). For many other countries, however, tax competition has resulted in a diminished ability to raise tax revenue on capital. For high-income countries, the main effect of tax competition is likely a shift of the tax burden towards less mobile factors such as labor income and consumption (Clausing, 2016). The result of tax competition, in these cases, is not so much an undersupply of public goods 
as a reduction of the part of the tax burden that is carried by those at the top of the distribution. Low-income countries, on the other hand, have often been unable to make up for their losses in corporate tax revenue, partly because they lack the institutional capacity to raise other kinds of taxes (Dietsch and Rixen, 2014b: 156). While OECD countries typically have a total tax revenue in the range of $30 \%$ to $40 \%$ of GDP, it is between $10 \%$ and $20 \%$ for developing countries. Tax avoidance through transfer pricing is at least part of the explanation why (European Parliament Directorate-General for External Policies of the Union, 2014).

\section{A problem of justice?}

To take stock of the discussion in the last section, there is evidence that international tax competition substantially hampers the ability of states to raise tax revenue on capital. For high-income states, the result is a shift of the tax burden towards less mobile tax bases, thus diminishing the part of the tax burden borne by those at the top of the distribution. Lowincome states, on the other hand, may have no choice but to shrink their budget substantially. For them, it is not only redistributive taxation that becomes more difficult, but taxation tout court.

Not all normative theorists will agree that this situation amounts to an injustice. Right libertarians may welcome the fact that tax competition impedes redistributive policies, which they take to be unjust in the first place (e.g. Nozick, 1974). Statists will claim that the scope of distributive justice is firmly limited to the domestic arena and demands for global justice in distributive matters are misguided (e.g. Nagel, 2005). I will not engage with these views in this article. Instead, I will simply assume that they are mistaken. This still leaves ample room for different normative background assumptions. Importantly, both cosmopolitan and 
internationalist theorists have reason to see international tax competition as a problem of justice (Ronzoni, 2014, 2016).

According to the kind of cosmopolitanism I am concerned with here, the demands of distributive justice apply, at least under conditions of a globalized economy, beyond state borders (Beitz, 1979; Pogge, 1994). What is problematic about international tax competition, on this view, is its effect on the global distribution of wealth, basic goods, welfare, or some other currency of distributive justice among individuals (call this the 'individualist equality' motive for action against harmful tax competition).

Internationalists, on the other hand, agree with statists that the demands of individualist distributive justice are restricted to the domestic context. The main subjects in the international arena are states rather than individuals, and an unequal distribution between individuals in different states is not problematic per se. However, what differentiates internationalists from statists is that they accept demands of background justice to secure conditions that enable all states to be functioning self-determining polities and to interact with each other as free and equal (Ronzoni 2009, 2014, 2016). ${ }^{6}$ Importantly, the self-determination of states is understood to entail not only freedom from external intervention, but also substantive abilities to solve their own problems, on their own terms. (This is often referred to as 'effective self-determination' or 'effective sovereignty'.)

On the internationalist view, tax competition is problematic mainly because it undermines effective self-determination in its fiscal dimension, i.e. the ability of states to effectively affect parameters of their domestic economies through their fiscal policies. Additionally, internationalists may also be concerned about the impact of tax competition on inequalities between states, as such inequalities may facilitate domination of one state by another, thus 
undermining the fairness of international relations. (Call these the 'fiscal self-determination' and 'inter-state equality' motives for action against harmful tax competition.)

I will not try to defend either the cosmopolitan or the internationalist view here. Instead, I will argue that a case can be made on both views for a robust institutional mechanism to prevent harmful tax competition. While the details of the preferred solution will likely depend on whether one accepts the cosmopolitan or the internationalist picture, there is also a large amount of convergence.

\section{The membership principle and the fiscal policy constraint}

To make the case for a robust institutional solution to the problem of harmful tax competition, it may be helpful to contrast my own view with the position of Dietsch and Rixen (2014b; for a more comprehensive defense, see Dietsch, 2015), who offer probably the most nuanced philosophical treatment of international tax competition to date. Relying mainly on the fiscal self-determination motive and with the ambition to remain neutral between competing substantive theories of distributive justice, they propose two side constraints on national tax policies to prevent harmful tax competition.

Their first principle, which they label the 'membership principle', demands that natural persons and companies pay taxes in the state (or states) whose infrastructure and public goods they use. Dietsch and Rixen motivate this principle using the following example: Assume that there are two health clubs on the same street, an expensive one with high-end equipment and extensive services, and a cheaper, less fancy one. As it turns out, membership cards of the cheaper club let visitors pass the turnstile at the high-end club, too, and a large number of costumers of the high-end club avoid its higher fees by purchasing a membership card from the cheaper club. Would it be just to stop this practice? Of course it would, and much to the 
same effect, Dietsch and Rixen argue, we should accept a principle that obliges individuals and companies to pay taxes where they actually live or operate. The hiding of portfolio capital in tax havens, as well as the practice of shifting profits to low-tax jurisdictions by manipulating transfer prices, are thus impermissible (Dietsch and Rixen, 2014b: 157-161). While the membership principle prohibits practices of 'poaching' (that is, attracting tax base that is moved purely on paper), Dietsch and Rixen's second principle bans some (though not all) forms of 'luring' (attracting tax base where this correlates with a real relocation of business activities or residence). The second principle is a fiscal policy constraint that consists of two parts (Dietsch and Rixen, 2014b: 161-166). A tax policy is prohibited if it (a.) diminishes the aggregate extent of fiscal self-determination internationally ('outcomes component'), and (b.) is motivated by strategic considerations in the sense that the policy would not be adopted if it weren't for the additional tax base that it attracts from abroad ('intentions component').

The outcomes component makes sure that a tax policy is still allowed, even if it is motivated by strategic considerations, if it has positive or neutral consequences on fiscal selfdetermination internationally. The intentions component is motivated by the thought that there is nothing wrong with states choosing low tax rates for non-strategic reasons. For example, if the English have a preference for a smaller state and less redistribution than the Swedish, Dietsch and Rixen (2014b: 162) see no justification for interfering with that choice on internationalist grounds. (I will challenge this assumption in the next section.)

Both the membership principle and the fiscal policy constraint are to be enforced by an International Tax Organization (ITO) with a dispute settlement body similar to the one currently in place in the World Trade Organization (Dietsch and Rixen, 2014b: 166-170). 


\section{Three objections against the fiscal policy constraint}

I believe that we should accept something along the lines of the membership principle, and if it were observed universally, some of the most harmful practices of tax evasion and tax avoidance would be eliminated. But as Dietsch and Rixen (2014b: 160-161) note, doing away with profit shifting may result in higher levels of real business relocation. The membership principle does not solve the externality problem described by the Zodrow/Mieszkowski model of capital tax competition introduced in section 2. Rather, it moves us from a situation that is worse than what is described by the model to the externality problem the model depicts. Individual states are still faced with an (asymmetric) prisoner's dilemma, where individual jurisdictions have an incentive to lower tax rates, even though higher rates would be better for all (or all could be made better off if side-payments were possible). It is Dietsch and Rixen's' solution to this problem that I find less convincing for three interrelated reasons.

First, there is the problem of identifying strategic intentions. How should we decide in practice whether a specific change in the tax code is motivated by strategic considerations? Dietsch and Rixen (2014b: 168-169) discuss this problem in terms of the potential for hypocritical misrepresentations of a government's actual motives. In response, they suggest to rely as much as possible on observable implications of a country's intentions, much like this is currently done in the case of non-tariff trade barriers under WTO regulations. Non-tariff trade barriers are generally prohibited, except if they are put in place to protect consumer safety and health. Governments may be asked to prove their good intentions by presenting scientific evidence that the policy in question does indeed serve these goals. A similar solution, Dietsch and Rixen argue, may be used to operationalize the fiscal policy constrain. I do not find this analogy entirely convincing. In the WTO case, the approach is one of white listing, with permissible intentions relying on a relationship between a means (the trade 
barrier) and an end (consumer safety or health). An objective test is possible because this means-end relation may or may not hold up to scrutiny. In the tax case, by contrast, the approach is one of black listing. All intentions except for strategic ones are permissible. Permissible motives may thus include non-instrumental considerations. For instance, a government might claim that it simply finds lower tax rates more just, because the rich have too much of a tax burden to carry already. In this case, there is no means-end relation to rely on in designing an objective test.

Also, the problem may run deeper than merely exposing hypocritical misrepresentations of real intentions, for the ascription of a unitary intention to the complex array of agents involved in the making of tax law may itself be problematic (Risse and Meyer, 2016). For example, what counts as the intention of a parliament that decides on tax cuts, if some of its members have a non-strategic preference for low taxes, while others primarily want to attract foreign capital? What about a situation where individual citizens strategically vote principled low-tax politicians into office in order to evade the fiscal policy constraint and enable low-tax policies (which these citizens themselves favor for strategic reasons)?

A second objection concerns the fact that the fiscal policy constraint seems to exhibit a problematic status quo bias. At least this is the case if the constraint is applied to changes in the tax code, as Dietsch and Rixen $(2014 \mathrm{~b}: 164,168)$ seem to suggest when they talk about its operationalization. If so, starting to apply the constraint at any given time will give an unfair advantage to those jurisdictions that already have measures to attract foreign capital in place. Not only are they under no obligation to change their tax code, but the fiscal policy constraint also protects them from competition by new low-tax jurisdictions. Besides inviting fairness objections, this status quo bias will likely lead to increased strategic behavior in the run-up to an agreement to implement the fiscal policy constraint. 
To avoid this problem, we might favor an alternative interpretation of the fiscal policy constraint. On this wider interpretation, states would be obliged to change any standing policies that deviate from the policies that would be in place if strategic considerations played no role in political deliberation (except where deviations from the non-strategic baseline have a beneficial or neutral effect on effective fiscal self-determination internationally). While this wider interpretation avoids the problem of status quo bias, it amplifies the problem of identifying strategic intentions. To decide whether a policy violates the constraint, we now need a full specification of the tax policies a country would presently have if strategic considerations had never played a role. Given the path dependence of developments in tax policy (the choices of a non-strategically motivated agent today presumably depend on the policies adapted earlier on), this necessitates rather sophisticated exercises in alternate history. We would need to go back in time to the point where arguments about tax competition first entered political debates and make judgements about what would have happened, until today, if these arguments had never been made.

Third and most importantly, there is the problem of asymmetrical restraint. The intentions component makes the fiscal policy constraint a version of the 'doctrine of double effect' (Risse and Meyer, 2016). Adopting one and the same policy, in full knowledge of its consequences, will be either permissible or impermissible depending on whether these consequences are intended or merely foreseen. Let us assume that in one country taxes on capital are lowered by right libertarians who believe that owners have too much of tax burden to carry already, while in another country, the same policy is enacted by social democrats who think that, while a higher tax rate would be warranted in an ideal world, a lower rate is needed in the real world to attract capital. Should we say that the policy in question should be allowed in the first case but not in the second, because the inflow of capital from abroad was merely 
foreseen in the first case, while it was intended in the second? Dietsch and Rixen (2014b: 162) think so. If we are to remain neutral between different tax policy preferences and corresponding substantive theories of distributive justice, they argue, we have to accept lowtax policies as long as they are chosen for non-strategic reasons (cf. Rixen, 2018: 119). However, this line of argument has awkward implications. Note that the fiscal policy constraint bans not only proactive but also reactive strategic behavior. Assume that the libertarian country has non-strategically lowered its taxes on capital, thus attracting tax base from the social democratic country. If social democrats now want to make up for some of their losses by enacting a moderate tax cut, the libertarians will have a case against them before the ITO's dispute settlement body, even if the net flow of tax base is still from the social democratic country to the libertarian one.

To make things worse, it may well turn out that the fiscal policy constraint does nothing to stop countries with a principled preference for low tax rates from approximating, in the long run, the policies they would adopt if strategic tax competition were allowed. While they are not allowed to take into account the expected influx of capital before it happens, the fiscal policy constraint still allows them to adjust their tax rates non-strategically after gaining additional tax base.

To illustrate the point, consider a stylized two-country scenario with 'England' (with a preference for low taxes) and 'Sweden' (with a preference for higher taxes), both starting off with the same tax scheme (cf. Dietsch and Rixen, 2014b: 162). At $\mathrm{t}_{1}$, in accordance with their respective non-strategic preferences, England lowers its tax rate on capital, while Sweden raises capital taxation. Some capital from Sweden flows into the English economy. This is not the end of the story, however, for it seems plausible that tax preferences are not preferences for a fixed tax rate. Rather, they are preferences for a certain tax rate, given a certain size of 
the tax base. Now assume that the preferred tax rate depends negatively on the amount of capital in the economy. ${ }^{7}$ At $t_{2}$, England readjusts its rate of capital taxation. Given that the tax base is now larger, a somewhat lower tax rate will suffice to finance public expenditure at England's preferred level. Sweden, on the other hand, will be forced to raise their tax rate even higher, regardless of the fact that they will lose even more capital to England. ${ }^{8}$ In the long run, England's non-strategic choices will iteratively approximate the tax policies the country would adopt if it were allowed to choose strategically. The Swedish, on the other hand, will be forced to move ever further away from the policies they would choose in a strategic scenario: Every time the country loses some of its tax base, it is forced to choose an even higher tax rate.

Perhaps one might think that these implications, awkward as they might seem, are simply the price we have to pay if we are to remain neutral between different substantive conceptions of distributive justice. In fairness, it should be noted that Dietsch and Rixen's claim is not that a more robust institutional mechanism to prevent harmful tax competition (such as the introduction of minimum tax rates) is unjustifiable full stop. ${ }^{9}$ Rather, their claim is that such a regime cannot be justified on the minimalist normative premises from which they proceed. If we are committed to a substantive theory of justice that favors relatively high tax rates, we may criticize low-tax policies even if they are chosen for non-strategic reasons. But if we abstain from such substantive premises and limit ourselves to the internationalist motive of protecting effective fiscal self-determination, there is no justification for interfering with countries that act on a genuine preference for low tax rates (Dietsch and Rixen, 2014b: 162; Dietsch, 2016: 244-245; Rixen, 2018: 119).

I disagree. Even if we treat tax preferences like any other morally neutral preferences, it is all but clear why we should favor a preference-dependent rule of conduct (where what you may 
do depends on your non-strategic preferences) over preference-independent rules of conduct (where everybody is subject to the same constraints).

To see why, imagine a system of noise control that is roughly analogous to the fiscal policy constraint. Individuals would have a right to play music at whatever volume and time they wish, as long as this reflects their genuine preferences. However, to avoid an escalation of the noise level in public parks and densely populated areas, there would be a ban on strategically adapting to the noise created by other people. If you really prefer listening to music at a low volume but cannot hear your own stereo because of the loud music coming through from your neighbor's place, you may not turn up the volume.

I take it that this would hardly count as a fair way of dealing with the fact that preferences for loud music and preferences for silence cannot be fully satisfied at the same time. Nor would such regulation have the virtue of being particularly neutral between different preferences. Rather, this asymmetrical restraint regime of noise control may be criticized as being unfair for two distinct reasons. First, strategic adaptors may rightly object that they are unfairly disadvantaged in comparison to those with a genuine preference for loud music: Not only is their first-best preference (listening to their own music at a low volume) not fulfilled, but they are also prevented from realizing their second-best preference (listening to their own music at a higher volume, rather than hearing their neighbor's). After all, strategic adaptors might say, they do genuinely prefer turning up the volume under the circumstances of a loud environment. Why should they not be allowed the same level of noise emission as those with a non-strategic preference for loud music? Second, silence lovers might object that the system does not take their interests into account sufficiently. After all, they are negatively impacted by loud music even in non-strategic cases. Rather than striking a fair balance, the rule under considerations simply lets music lovers have it their way as long as they follow their non- 
strategic preferences. Note that neither of these complaints depends in any way on there being a principled objection to loud music. The objections can be cashed out entirely in terms of an unequal satisfaction of preferences under a system of asymmetrical restraint.

Similar objections can be raised against the fiscal policy constraint. First, strategic adaptors may rightly object to the asymmetrical constraint imposed on their option space. Why should they be obliged to refrain from enacting low-tax policies, given that they prefer these policies under the circumstances and other countries are allowed to enact them? Second, low-tax policies negatively impact countries with high-tax preferences regardless of whether they are chosen for strategic reasons. Granting one country the right to act on its non-strategic preference for very low tax rates will therefore limit the ability of other countries to act on their genuine preferences for a larger public budget and more redistributive policies. In other words, there is a conflict here between the claims of different countries to effective selfdetermination, and there is no reason to believe that a fair solution, in such a situation, is to adjudicate this conflict in favor of the country with low-tax preferences. Again, these criticisms do not depend on a principled case against low-tax preferences based on a substantive theory of distributive justice.

I do not want to claim that there is a full analogy between the noise case and the tax case. But both cases share an important structural feature. Loud music and low taxes both impose negative externalities on those with different preferences, but not vice versa (if anything, the silence of others helps music lovers realize their preferences, and high tax rates in other countries help low-tax jurisdictions realize their policy goals). If we discount the possibility of full sound-proofing, it is impossible to fully satisfy preferences for silence and preferences for loud music at the same time. Similarly, if we discount the possibility of immobilizing the tax base (e.g. by reintroducing capital controls), there is no way low-tax preferences and high-tax 
preferences can be fully satisfied simultaneously. A fair solution will have to strike some kind of balance between both kinds of preferences.

In conclusion, even if we assume that there is nothing intrinsically wrong with a preference for low tax rates, that there are uniform preferences among the citizens of a state and that governments trace these interests perfectly, it is far from clear that there should be an unlimited right to low tax rates.

\section{A more robust solution}

If my arguments so far are convincing, we should reject Dietsch and Rixen's preferencedependent fiscal policy constraint in favor of a more robust, preference-independent mechanism to limit downward pressure on the taxation of mobile tax bases. This more robust mechanism will also be targeted at a broader problem: It will not only address the harmful effects of tax competition in the strict sense (where countries act strategically to attract tax base), but it will address the broader externality problem created by uncoordinated tax setting under conditions of (partial) factor mobility, which persists even in the absence of strategic behavior.

What could such a more robust mechanism look like? The most radical solution would certainly be to centralize the power to raise taxes on mobile tax bases in the hands of an international institution. From a cosmopolitan point of view, this is presumably an attractive solution, at least if we set aside concerns about institutionalization and the concentration of power. If the problem of the current tax regime is that it results in an unjust distribution between individuals worldwide, then global taxation (combined with a global system of transfers) is an obvious response. From an internationalist perspective, however, this solution would amount to throwing the baby out with the bathwater. If the negative externalities 
created by low-tax policies are problematic because they undermine effective fiscal selfdetermination, then getting rid of fiscal self-determination entirely will hardly count as an attractive solution.

A somewhat more moderate solution, then, might be a mixed system that leaves the power to raise taxes on mobile tax bases with individual states, but introduces an additional layer of taxes and/or subsidies, to be raised and distributed by an international institution, which aims at internalizing the external effects of national tax policies. The general idea of such a system would be to disincentivize tax cuts at a rate that is equal, at the margins, to the costs these tax cuts create for other jurisdictions. Conversely, an increase in national tax rates would be incentivized, with the marginal size of the incentive equal to the marginal benefit all other states receive from the resulting influx of capital. ${ }^{10}$

This would be an elegant solution, because states would remain free to set tax rates at whatever level they wish, as long as they are willing to bear the costs this choice imposes on other states. But whatever its merits, such an internalization mechanism is presumably far beyond what is politically feasible. First, it presupposes an international institution with the power to tax, which seems like a remote possibility at best. Second, there is a myriad of ways to implement such a system, each with a different impact on global distribution, and it would be very difficult to reach agreement on one specific implementation. ${ }^{11}$ I will therefore not pursue this internalization mechanism any further here.

Instead, in the remainder of this paper, I will defend a simpler mechanism to mitigate downward pressure on the taxation of mobile tax bases: the introduction of internationally binding minimum tax rates (cf. Ronzoni, 2016: 211-212). This mechanism would leave the power to tax in the hands of individual states. However, tax rates below a commonly defined threshold would be prohibited. Compliance would have to be enforced by an international 
institution with sufficient means do deter defection. The most obvious application would be a minimum tax rate on corporate income, though given the mobility of wealthy individuals and top earners, the same principle could also be applied to taxes on property or inheritances, or the highest bracket of personal income taxation.

In comparison to the internalization solution, minimum tax rates may be seen as suboptimal in two ways. First, states will be unable to maintain tax rates below the threshold, even if they are willing to pay fully for the external costs of their choices. Second, harmful tax competition may persist on a smaller scale beyond the threshold. Nevertheless, a minimum tax rate that balances these two sources of suboptimality will likely mitigate the harmful effects of international tax competition substantially. Importantly, tax competition above the threshold is not unaffected by the existence of a minimum tax rate (Keen and Konrad, 2013: 288-292). States that had a tax rate just above the threshold before the introduction of a minimum tax rate will now feel less pressure from states with very low tax rates and adjust their own tax rate accordingly. This, in turn, will decrease pressure on states with higher tax rates.

Admittedly, there are feasibility questions about this solution, too. Saying that chances for the implementation of global minimum tax rates are currently slim is probably an understatement. Even within the European Union, where fiscal interdependence is arguably most pronounced due to the single market, little progress has been made so far to tackle harmful tax competition, partly because low-tax jurisdictions that benefit from the lack of coordination can block regulation under the EU's unanimity rule (Wasserfallen, 2014). There is currently no common definition of the tax base, which is a prerequisite not only for effective minimum tax rates, but also for an implementation of the membership principle in the form of unitary taxation with formulary apportionment (cf. Dietsch and Rixen 2014b: 167-168). However, 
both the European Commission (2016) and European Parliament (2018) still push for a common consolidated corporate tax base (CCCTB) within the EU, and demands for a minimum tax rate on this commonly defined tax base come up now and again in the debate surrounding CCCTB. Most recently, the European Parliament Committee on Legal Affairs has called for a minimum tax rate of $25 \%$ on corporate income within the EU (European Parliament Committee on Economic and Monetary Affairs, 2018). ${ }^{12}$ While it is unlikely that such a minimum tax rate will be enacted anytime soon, it is not entirely outside the realm of political possibility, and it is at least conceivable that such a European solution could later be scaled to a more encompassing international framework.

Another (perhaps more problematic) route towards global minimum tax rates would be to rely on unilateral measures by economically powerful jurisdictions. One proposal of this kind was put forward by former U.S. senator Max Baucus in 2013. The Baucus plan would have set a minimum tax rate on the income of U.S. corporations' foreign subsidiaries at either $80 \%$ or $60 \%$ of the U.S. tax rate, regardless of whether profits are repatriated. The plan would have disincentivized foreign tax rates below the minimum by levying a tax in the U.S. to make up for any difference to the minimum tax rate (Christians, 2013; Dietsch, 2015: 70-75). In sum, I believe that global minimum tax rates are not entirely infeasible in the long run. And they are a measure both cosmopolitans and internationalists have reason to support. Of course, theorists in both camps will disagree about the ultimate justification of minimum tax rates. Cosmopolitans will point to their positive impact on global distributive justice, while internationalists will see them as a circumscription of de jure sovereignty in the interest of protecting de facto sovereignty. Also, cosmopolitans will likely be in favor of a more encompassing reform of the global tax regime if that proves feasible at some point in the 
future. But I think that cosmopolitans and internationalists can both agree that internationally binding minimum tax rates would be a step in the right direction.

\section{Setting the global minimum tax rate}

At what level, then, should the minimum tax rate on a given mobile tax base be set? To give a precise response to this question, we would need not only a wealth of empirical information, but also a full-fledged (cosmopolitan or internationalist) theory of justice, both of which I cannot provide here. Instead, I will limit myself to some remarks on how we might go about setting the minimum tax rate, thus addressing the worry familiar from the debate about sufficientarianism that any threshold will necessarily be arbitrary (Casal, 2007).

From a cosmopolitan perspective, the relevant question is about the distribution of basic goods (or welfare, or any other currency of justice) among individuals. We should choose the minimum tax rate that leads to a global distribution that satisfies the preferred principle of justice. This may be a sufficientarian principle (what minimum tax rate enables all states to guarantee a certain social minimum to their inhabitants?), it may be a global difference principle (what minimum tax rate maximizes the holdings of the worst-off globally?) or any other principle of global distributive justice. Determining the preferred minimum tax rate on any of these theories will obviously be a difficult empirical task, but the normative basis for setting the minimum is relatively straightforward.

From an internationalist perspective, on the other hand, the minimum tax rate should be chosen with an eye to its effects on the effective fiscal self-determination of states. ${ }^{13}$ There are two theoretical questions about this choice. First, how exactly should we understand fiscal self-determination, and how can it be measured in practice? Second, how should we choose between different distributions of fiscal self-determination among states? 
Let us start with the measurement question. In the literature, effective fiscal selfdetermination is typically understood to be a function of the choices available to a country regarding two broad characteristics of its economy, namely the size of its public sector and the distribution of burdens and benefits among individuals within the country (Dietsch and Rixen, 2014b: 153; Dietsch, 2015: 35; Ronzoni, 2014: 42-43; van Apeldoorn, 2018: 481-482). The greater a country's ability to effectively affect these parameters through its policy choices, the greater its fiscal self-determination.

There is an interesting question about whether these factors should be understood in relative or in absolute terms. Does a state's effective fiscal self-determination depend on how well it can affect the size of its public budget relative to GDP, or do wealthier states enjoy a higher level of effective self-determination, because they can reach higher levels of public spending in absolute terms? Is a state's ability to affect distribution to be measured in terms of its control over relative inequality (as measured, for example, by the Gini coefficient), or in terms of the absolute level of economic welfare it can provide to those at the bottom of the distribution?

Most internationalists seem to endorse a relative understanding (e.g. Dietsch, 2015: 35; van Apeldoorn, 2018: 481-482). At first sight, this seems attractive because it allows us to isolate the issue of fiscal self-determination from issues of international distribution. At least in theory, a poor country could enjoy full fiscal self-determination in the relative sense. However, this relative understanding has awkward implications. Public spending relative to GDP could be increased simply by shrinking GDP while keeping public spending constant, and relative inequality could be reduced simply by making everybody poor. However, if a state is able to raise a large public budget relative to GDP only by drastically reducing GDP itself, or if it has the ability to reduce inequality only by making everybody worse-off, it 
seems counterintuitive that this should count as a sign of a high level of effective fiscal selfdetermination. (The charge against international tax competition is of course exactly that it creates this kind of situation. Strictly speaking, tax competition does not prevent countries from enacting redistributive policies or spending a large part of their GDP for public goods, it prevents them from doing so without losing capital and thereby shrinking their economy.) I take it, therefore, that we should favor an absolute understanding of effective fiscal selfdetermination, which brings internationalism closer to cosmopolitanism in that it gives internationalists additional reason to worry about the international distribution of wealth. But let us put these issues aside and assume that we have a plausible measurement of a state's ability to affect distribution and public sector size in place. How does a global minimum tax rate (say, on corporate income) affect this ability? To be sure, there is no one-to-one relationship between a state's ability to raise tax revenue on one specific tax base and its ability to reach its policy goals regarding public sector size and redistribution. Rather, we have to assess how well a state can reach these goals using all the tools at its disposal, both on the tax side and on the spending side. But as I have argued above, it seems plausible that there is no perfect substitute for taxes on mobile tax bases. A country may substitute corporate income taxes with taxes on labor or consumption to finance the same public budget, but not without resorting to a more regressive policy mix overall. ${ }^{14}$

There is, then, a relationship between fiscal self-determination and the option space available to a jurisdiction in taxing mobile tax bases. This option space may be represented using the so-called Laffer curve, which maps rates of taxation to corresponding levels of tax revenue. ${ }^{15}$ A minimum tax rate takes away some options (all tax rates left of the minimum are off the table), while at the same time changing the shape of the Laffer curve right of the minimum (the jurisdiction will now be able to raise more revenue at higher tax rates). 
Each level of minimum taxation will result in a different Laffer curve, and the question is which of these option spaces gives the state in question the most fiscal self-determination overall. At first approximation, we might ask which minimum tax rate offers the single best policy option to a jurisdiction, in terms of best fulfilling its preferences for redistribution and the provision of public goods. But internationalists are concerned not so much with optimality as with choice. If a country had only one policy option, which accidentally fulfilled its preferences perfectly, it would plausibly enjoy very limited self-determination. ${ }^{16}$ This means that we should not limit ourselves to looking at one single set of preferences, but instead evaluate how well a jurisdiction can fulfil different tax preferences under any given minimum tax rate. Ideally, we need an index of fiscal self-determination that allows us to reduce the whole option space to a single value, and I have no comprehensive response to how we might go about constructing such an index. But it seems obvious that any plausible operationalization of the notion of effective fiscal self-determination will be concerned not merely with the number of options available to a jurisdiction, but also with their value. As Dietsch (2016: 244) puts it, '[t]he formal liberty of choosing your tax rate becomes meaningless if choosing a high rate will result in capital outflows that seriously dent revenues'. While it is obviously true that the number of options decreases with any increase of the minimum tax rate, this will be offset, for some levels of minimum taxation, by the fact that the remaining options become more valuable. Up to a certain point, the circumscription of de jure sovereignty will enhance a jurisdiction's de facto sovereignty.

Where exactly this tipping point is situated will depend on a number of factors, including the size of the economy in question and other country specific characteristics. Therefore, there will likely be a range in which an increase in the global minimum tax rate will enhance the effective sovereignty of some states while at the same time diminishing the effective 
sovereignty of others. This leads us to the second question: How should we choose between different distributions of effective fiscal self-determination among states?

Much like cosmopolitans disagree about the preferred distributive pattern among individuals, so internationalists could defend different principles for a just distribution of effective fiscal self-determination among states (van Apeldoorn, 2018). They could be sufficientarians (each jurisdiction should enjoy a certain minimum level of effective self-determination) or strict egalitarians (equal self-determination for all), they could be concerned with raising the effective self-determination of the worst-off jurisdiction, or they could be sum-maximizers (endorsing the view that we should maximize the total amount of effective fiscal selfdetermination enjoyed by all states). ${ }^{17}$

Which of these versions of internationalism we should favor is up for debate, as is the preferred measurement of effective fiscal self-determination. But it is important to note that these problems are not specific to the policy proposal at hand. They also come up in the operationalization of the Dietsch/Rixen solution, ${ }^{18}$ and more generally, internationalists who want to evaluate any regime of global tax governance will likely need a response to these questions.

While I have not been able to devise a precise response to how high the minimum tax rate should be, I hope to have shown that it need not be arbitrary. Once we have a fully specified theory of justice on either cosmopolitan or internationalist grounds, determining the preferred level of minimum taxation will be an empirical task. If my considerations are convincing, this preferred level will not be zero on either account. 


\section{Accommodating the needs of low-income countries}

Let us now turn to the worry that global minimum tax rates may end up harming those countries that are already among the worst-off globally. If competition for mobile capital on the basis of low tax rates is limited, other location factors such as public infrastructure or the education level of the workforce will likely gain in importance. Countries that do not have much to offer in this regard will be left with little or no possibility to attract foreign direct investment. And without capital flowing into the jurisdiction, they may not be able to raise the tax revenue necessary to improve public infrastructure or education. Should we exempt lowincome countries from global minimum tax rates to create a pathway out of this trap? If there were only one low-income country in the world, a blanket exception would probably be a defensible solution. This country would likely choose a tax rate somewhat lower than the minimum for all other countries, but it would still be able to raise substantial tax revenue on the inflowing capital. However, in the real world there is more than one low-income country. If a blanket exception is made for all of them, a race to the bottom among them would be the likely effect, leaving them unable to raise enough tax revenue to finance much needed public investments.

A preferable solution, therefore, would be one that involves a direct redistribution of financial means (Dietsch and Rixen, 2014b: 166), which could be used to improve education and public infrastructure. If this first-best solution is not feasible, maybe a differentiated system with two different minimum tax rates, a lower one for low-income countries and a higher one for everyone else, may be an acceptable second-best solution. But a blanket exception would not only be costly for higher-income countries, it would also hardly serve the interests of lowincome countries themselves. 


\section{Conclusion}

Dietsch and Rixen are to be credited not only with substantiating Ronzoni's (2009) earlier claim that tax competition undermines international background justice, but also with coming up with a plausible normative solution to the problems associated with offshore tax havens and profit shifting. What is less convincing, this paper argued, is the fiscal policy constraint they propose to limit downward pressure on capital taxation caused by competition for foreign direct investment. Instead, both cosmopolitans and internationalists should lobby for the introduction of global minimum tax rates on mobile tax bases. Theorists in both camps may disagree about the direction global tax governance should take in the long run.

Internationalists will want to protect the fiscal self-determination of states, while cosmopolitans may want to move away from a state-centered system altogether. In the meantime, however, global minimum tax rates are a step in the right direction from both perspectives.

\section{Acknowledgements}

Earlier versions of this paper were presented in Berlin, Hamburg and Zurich. I would like to thank all those present at these events for their valuable comments. For extensive feedback, I am especially grateful to Jan Brezger, Peter Dietsch, Sabine Hohl, Daniel Jacob, Bernd Ladwig, Luise Müller, Merten Reglitz, Thomas Rixen, Cord Schmelzle, Juri Viehoff, Andrew Williams and two anonymous reviewers of Politics, Philosophy \& Economics.

\section{Funding}


This research was funded by the Swiss National Science Foundation (grant number P2ZHP1_158865).

\section{References}

Auerbach M (2016) IKEA: Flat Pack Tax Avoidance. Study commissioned by the

Greens/EFA Group in the European Parliament. Available at: https://www.greensefa.eu/legacy/fileadmin/dam/Documents/Studies/Taxation/Report_IKEA_tax_avoidanc e_Feb2016.pdf (accessed 7 February 2019).

Baldwin RE and Krugman P (2004) Agglomeration, integration and tax harmonization. European Economic Review 48(1): 1-23.

Beitz CR (1979) Political Theory and International Relations. Princeton, New Jersey: Princeton University Press.

Brock G (2008) Taxation and Global Justice: Closing the Gap between Theory and Practice. Journal of Social Philosophy 39(2): 161-184.

Bucovetsky S (1991) Asymmetric tax competition. Journal of Urban Economics 30(2): 167181.

Carens JH (1987) Aliens and Citizens: The Case for Open Borders. The Review of Politics 49(2): $251-273$.

Carens JH (2013) The Ethics of Immigration. Oxford: Oxford University Press.

Casal P (2007) Why Sufficiency Is Not Enough. Ethics 117 (2): 296-326.

Casal P (2012) Progressive Environmental Taxation: A Defence. Political Studies 60(2): 419433.

Cassee A (2016) Globale Bewegungsfreiheit: Ein philosophisches Plädoyer für offene Grenzen. Berlin: Suhrkamp. 
Christians A (2013) What the Baucus Plan Reveals About Tax Competition. Tax Notes International 72 (December 23).

Clausing KA (2016) The Nature and Practice of Tax Competition. In: Dietsch P and Rixen T (eds), Global Tax Governance: What is wrong with it and how to fix it, Colchester: ECPR Press, pp. 27-53.

de Mooij RA and Ederveen S (2008) Corporate tax elasticities: A reader's guide to empirical findings. Oxford Review of Economic Policy 24(4): 680-697.

Dietsch P (2015) Catching Capital: The Ethics of Tax Competition. New York: Oxford University Press.

Dietsch P (2016) Whose Tax Base? The Ethics of Global Tax Governance. In: Dietsch P and Rixen T (eds), Global Tax Governance: What is wrong with it and how to fix it, Colchester: ECPR Press, pp. 231-251.

Dietsch P and Rixen T (2014a) Redistribution, Globalisation, and Multi-level Governance. Moral Philosophy and Politics 1(1): 61-81.

Dietsch P and Rixen T (2014b) Tax Competition and Global Background Justice. Journal of Political Philosophy 22(2): 150-177.

European Commission (2016) Proposal for a Council Directive on a Common Consolidated Corporate Tax Base (CCCTB). Available at: https://eur-lex.europa.eu/legalcontent/EN/TXT/?uri=CELEX\%3A52016PC0683 (accessed 7 February 2019).

European Parliament (2018) European Parliament legislative resolution of 15 March 2018 on the proposal for a Council directive on a Common Consolidated Corporate Tax Base (CCCTB). Available at: http://www.europarl.europa.eu/sides/getDoc.do?pubRef=//EP//TEXT+TA+P8-TA-2018-0087+0+DOC+XML+V0//EN (accessed 7 February 2019). 
European Parliament Committee on Economic and Monetary Affairs (2018) Report on the proposal for a Council directive on a Common Consolidated Corporate Tax Base (CCCTB). Available at:

http://www.europarl.europa.eu/sides/getDoc.do?type=REPORT\&reference=A8-20180051\&language $=\mathrm{EN}$ (accessed 7 February 2019).

European Parliament Directorate-General for External Policies of the Union (2014) Tax Revenue Mobilisation in Developing Countries: Issues and Challenges. Available at: http://www.europarl.europa.eu/RegData/etudes/etudes/join/2014/433849/EXPODEVE_ET(2014)433849_EN.pdf(accessed 7 February 2019).

Genschel P and Seelkopf L (2016) Winners and Losers of Tax Competition. In: Dietsch P and Rixen T (eds), Global Tax Governance: What is wrong with it and how to fix it, Colchester: ECPR Press, pp. 55-75.

Hayward T (2005) Thomas Pogge's Global Resources Dividend: a critique and an alternative. Journal of Moral Philosophy 2(3): 317-332.

Hirschman AO (1970) Exit, voice, and loyalty: Responses to decline in firms, organizations, and states. Harvard: Harvard University Press.

Hong Q and Smart M (2010) In praise of tax havens: International tax planning and foreign direct investment. European Economic Review 54(1): 82-95.

Keen M and Konrad KA (2013) The Theory of International Tax Competition and Coordination. In: Auerbach AJ, Chetty R, Feldstein M, Saez E (eds), Handbook of Public Economics, vol. 5, pp. 257-328.

Murphy LB and Nagel T (2002) The Myth of Ownership: Taxes and Justice. Oxford: Oxford University Press.

Nagel T (2005) The Problem of Global Justice. Philosophy \& Public Affairs 33(2): 113-147. 
Nozick R (1974) Anarchy, State, and Utopia. New York: Basic Books.

OECD (2019) OECD Statistics. Available at: https://stats.oecd.org/ (accessed 7 February 2019).

Piketty T (2014) Capital in the Twenty-First Century. Cambridge, Massachusetts: Harvard University Press.

Piketty T et al. (2014) Our manifesto for Europe. The Guardian, 02 May. Available at: https://www.theguardian.com/commentisfree/2014/may/02/manifesto-europe-radicalfinancial-democratic (accessed 7 February 2019).

Pogge TW (1994) An Egalitarian Law of Peoples. Philosophy \& Public Affairs 23(3): 195224.

Pogge TW (1998) A Global Resources Dividend. In: Crocker DA and Linden T (eds), Ethics of Consumption: The Good Life, Justice, and Global Stewardship, Lanham, Maryland: Rowman \& Littlefield, pp. 501-536.

Rawls J (1971) A Theory of Justice. Cambridge, Massachusetts: Belknap Press of Harvard University Press.

Risse M and Meyer M (2016) Review of Peter Dietsch, Catching Capital: The Ethics of Tax Competition. Notre Dame Philosophical Reviews. Available at:

http://ndpr.nd.edu/news/65483-catching-capital-the-ethics-of-tax-competition/ (accessed 7 February 2019).

Rixen T (2008) The Political Economy of International Tax Governance. London: Palgrave Macmillan.

Rixen T (2011) Tax Competition and Inequality: The Case for Global Tax Governance. Global Governance 17: 447-467. 
Rixen T (2016) Institutional Reform of Global Tax Governance: A Proposal. In: Dietsch P and Rixen T (eds), Global Tax Governance: What is wrong with it and how to fix it, Colchester: ECPR Press, pp. 325-349.

Rixen T (2018) Globalisierung und fiskalische Demokratie. Politische Vierteljahresschrift 59: $103-124$.

Ronzoni M (2009) The Global Order: A Case of Background Injustice? A Practice-Dependent Account. Philosophy \& Public Affairs 37(3): 229-256.

Ronzoni M (2014) Global Tax Governance: The Bullets Internationalists Must Bite - And Those They Must Not. Moral Philosophy and Politics 1(1): 37-59.

Ronzoni M (2016) Tax Competition: A Problem of Global or Domestic Justice? In: Dietsch P and Rixen T (eds), Global Tax Governance: What is wrong with it and how to fix it, Colchester: ECPR Press, pp. 201-214.

Slemrod J and Wilson J (2009) Tax competition with parasitic tax havens. Journal of Public Economics 93(11-12): 1261-1270.

Sørensen PB (2004) International tax coordination: regionalism versus globalism. Journal of Public Economics 88(6): 1187-1214.

Steiner H (2005) Territorial justice and global redistribution. In: Brock G and Brighouse H (eds), The Political Philosophy of Cosmopolitanism, Cambridge: Cambridge University Press, pp. 28-38.

Tiebout CM (1956) A Pure Theory of Local Expenditures. Journal of Political Economy 64(5): 416-424.

van Apeldoorn L (2018) BEPS, tax sovereignty and global justice. Critical Review of International Social and Political Philosophy 21(4): 478-499. 
Wasserfallen F (2014) Political and Economic Integration in the EU: The Case of Failed Tax Harmonization. Journal of Common Market Studies 52(2): 420-435.

Wildasin DE (1989) Interjurisdictional capital mobility: Fiscal externality and a corrective subsidy. Journal of Urban Economics 25(2): 193-212.

Wilson J and Wildasin DE (2004) Capital tax competition: bane or boon. Journal of Public Economics 88(6): 1065-1091.

Wollner G (2014) Justice in Finance: The Normative Case for an International Financial Transaction Tax. Journal of Political Philosophy 22(4): 458-485.

Zodrow GR and Mieszkowski P (1986) Pigou, Tiebout, property taxation, and the underprovision of local public goods. Journal of Urban Economics 19(3): 356-370.

Zucman G (2013) La Richesse cachée des nations: Enquête sur les paradis fiscaux, Paris: Seuil.

Zucman G (2014) Taxing across Borders: Tracking Personal Wealth and Corporate Profits. Journal of Economic Perspectives 28(4): 121-148.

\section{Author biography}

Andreas Cassee is a research fellow at the University of Bern. His research interests include justice in taxation, the ethics of migration and theories of moral complicity.

\footnotetext{
${ }^{1}$ Such proposals include a global wealth tax (Piketty, 2014), a global tax on the use of (Pogge, 1998) or ownership in natural resources (Steiner, 2005), a tax proportional to individual countries' ecological footprints (Hawyward, 2005), a progressive environmental tax (Casal, 2012), or an international financial transaction tax (Wollner, 2014).
} 
${ }^{2}$ For a discussion of problems concerning the definition and measurement of effective fiscal self-determination, see section 7.

${ }^{3}$ Notable exceptions include the models by Slemrod and Wilson (2009) and Hong and Smart (2010), which account for income shifting to tax havens.

${ }^{4}$ The furniture retailer IKEA is an instructive example (Auerbach, 2016): All national IKEA Group subsidiaries pays a fee for using the IKEA brand to Inter IKEA Systems BV, located in the Netherlands. This lowers IKEA's taxable profits in other countries. However, these profits are not taxed in the Netherlands, either. Until 2011, most revenue of Inter IKEA Systems BV was passed on to an undisclosed entity, presumably in a tax haven. In 2012, the Interogo Foundation in Liechtenstein sold the IKEA trademark to Inter IKEA Systems BV, so that in theory, profits on the trademark would now be taxable in the Netherlands. However, the sale of the trademark was financed by a $€ 5.4$ billion loan, leading to tax-deductible interest payments from Inter IKEA Systems BV in the Netherlands to Interogo Finance SA in Luxembourg, which paid an effective tax rate of just $0.06 \%$ between 2012 and 2014, while sending $€ 807.8$ million in dividends to Interogo Foundation in Liechtenstein.

${ }^{5}$ Tax competition optimists sometimes point out that despite declining statutory tax rates, corporate tax revenue as a percentage of GDP has remained stable or even increased since the 1980s in many OECD countries (OECD, 2019). However, there is evidence that effective corporate tax rates have indeed dropped, and that stable or increasing tax revenues are the result of higher corporate profits offsetting the downward pressure on corporate taxation (Clausing, 2016).

${ }^{6}$ On the kind of internationalism I am concerned with here, the scope of background justice includes all states that are in a position to dominate each other or undermine each other's 
effective sovereignty. On the argument under consideration, this includes all states between which capital is mobile.

${ }^{7}$ This may be the case for a number of reasons. First, a country's preference might take the sufficientarian form of a preference for a fixed level of basic provision. The larger the tax base, the lower the tax rate necessary to finance this basic provision. Second, the influx of capital might have effects in the private sector (such as lowering unemployment), which in turn decrease the preferred level of taxation (e.g. to finance unemployment benefits). Third, even if the preference is one for a tax revenue in the amount of a fixed percentage of GDP, there may be a negative correlation between tax base and preferred tax rate based on declining returns of capital. Note that my argument does not presuppose that there is always a negative correlation between the amount of capital in an economy and the preferred rate of capital taxation. It is enough that the correlation may plausibly be negative in some cases.

${ }^{8}$ The example assumes the wider interpretation of the fiscal policy constraint as discussed above. On the narrower interpretation, the Swedish will be allowed to stick with their standing policies, though the point about England's right to iteratively move to more aggressive lowtax policies still stands.

${ }^{9}$ Rixen (2011: 460) even argues in favor of minimum tax rates in other work that is less concerned with neutrality vis-à-vis different distributive preferences.

10 The same incentives could be realized using only taxes (the revenue of which would be spent in some other way), only subsidies (to be financed with some independent stream of revenue), or by a revenue-neutral combination of both. Wildasin (1989) proposes a subsidy model in the context of capital tax competition between U.S. states. He estimates that the marginal size of the subsidy should be up to $40 \%$ in a situation of perfect capital mobility. In 
other words, one dollar of additional tax revenue generated locally from an increase in capital taxation should be matched with a 40 cent national subsidy in order to offset externalities.

${ }^{11}$ There are different ways to implement such a system because the same marginal incentives can be realized by imposing different overall costs and benefits. As long as the marginal cost the system imposes on a jurisdiction for a tax cut equals the marginal negative externality this tax cut imposes on other jurisdictions, it does not matter, in terms of incentives, whether the state in question is a net beneficiary or a net payer.

${ }^{12}$ Also see 'Our manifesto for Europe' (Piketty et al., 2014), which calls for a 20\% minimum tax rate on corporate income in Europe and an additional $10 \%$ to be raised directly at the European level.

${ }^{13}$ Additionally, internationalists may also be interested in the impact of the minimum tax rate on inter-state inequality. As I will show below, this distributive concern can be integrated at least partly into the concern for effective fiscal self-determination: The minimum tax rate should be chosen with an eye to its effects on the distribution of fiscal self-determination among states. However, internationalists may also want to give some direct weight to the impact of the minimum tax rate on economic inequalities between states.

${ }^{14}$ Other forms of capital taxation such as personal capital income taxes, property taxes or inheritance taxes may be a closer substitute for corporate income taxes in terms of their impact on distribution, but those are subject to downward pressure from international tax competition, too.

15 The Laffer curve was originally used to illustrate an argument that high tax rates are counterproductive because, beyond a certain point, an increase in the tax rate will lead to lower tax revenue due to incentive effects. Many economists today doubt that tax rates right 
of this tipping point are ever observed in practice. My use of the Laffer curve does not depend on this assumption and is not meant as an endorsement of Laffer's larger argument.

${ }^{16}$ Ronzoni (2014: 43) captures this by adding a third aspect to her definition of effective fiscal self-determination. To be fiscally self-determining, on her view, a state needs not only the capacity to maintain the desired level of public budget and redistribution, but also flexibility in its fiscal policies over time. An alternative (and in my view preferable) understanding incorporates the concern for flexibility into the way we understand the first two aspects: not as the ability to maintain one specific level of public budget and redistribution, but as the ability to choose between different levels of public budget and redistribution.

${ }^{17}$ Van Apeldoorn (2018) discusses sufficientarian and egalitarian versions of internationalism. Dietsch and Rixen (2014b) seem to endorse a sum-maximizing view when they argue that strategically motivated tax policies should be prohibited if they reduce the aggregate extent of fiscal self-determination internationally.

${ }^{18}$ Remember that the fiscal policy constraint prohibits strategic tax policies only if they are harmful to effective fiscal sovereignty internationally. To apply this in practice, we need a measurement of effective fiscal sovereignty, and we need a distributive principle to deal with cases where a policy is beneficial to some states' effective sovereignty but harmful to others'. 